\title{
"Captar los conflictos más sutiles del alma" en el proceso de traducción. La poesía de Wisława Szymborska en gallego y en español
}

\author{
Aleksandra Jackiewicz ${ }^{1}$
}

Recibido: 18 de maio de 2019 / Aceptado: 25 de outubro de 2019

Resumen. El presente artículo tiene como propósito señalar los posibles obstáculos de traducción que encuentran los traductores al recrear el mundo representado en la poesía de Wisława Szymborska, galardonada con el Premio Nobel de Literatura en 1996. Nos proponemos efectuar un estudio comparativo entre los versos de partida y sus versiones gallegas y españolas para averiguar si la estructura estilístico-formal de las obras en las que trasluce "una vibración emocional e intelectual muy peculiar, debido a una mezcla de observaciones muy concretas y de un tono lírico sobrio, siempre atenuado por la ironía" (Rodowska 2008) se ha preservado en los textos de llegada. Nuestro estudio se basará en la idea de la traducción de textos líricos como una reelaboración del original en otro código lingüístico (Herrero Cecilia 1995) y en la teoría del "pensamiento lateral" (De Bono 1970), es decir, un modo de razonamiento imaginativo y anárquico, el cual dicta la organización funcional del cerebro que determina los hábitos de pensar. El análisis desarrollado siguiendo estas concepciones nos permitirá verificar hasta qué punto la estimulación en los traductores del desarrollo de su potencial recreativo para verter los versos polacos ha posibilitado al receptor percibir las cualidades de la realidad de partida. Asimismo, demostraremos que la intencionalidad estética de las representaciones originales puede funcionar en el contexto poético gallego y español sin mayores inconvenientes.

Palabras clave: poesía; traducción; pensamiento lateral; recreación; Wisława Szymborska.

\section{[gal] "Captar os máis sutís conflitos da alma" no proceso de tradución. A poesía de Wisława Szymborska en galego e en español}

Resumo. O obxectivo deste artigo é sinalar os posibles obstáculos de tradución que atopan os tradutores ao recrearen o mundo representado na poesía de Wisława Szymborska, gañadora do Premio Nobel de Literatura en 1996. Propoñemos realizar un estudo comparativo entre os versos de partida e as súas versións galegas e españolas para descubrir se a estrutura estilístico-formal das obras en que transloce "unha vibración emocional e intelectual moi peculiar, debido a unha mestura de observacións moi concretas e un ton lírico sobrio, sempre atenuado pola ironía" (Rodowska 2008) se preservou nos textos de chegada. A nosa análise basearase na idea da tradución de textos líricos como reelaboración do orixinal noutro código lingüístico (Herrero Cecilia 1995) e na teoría do "pensamento lateral" (De Bono 1970), isto é, un modo de razoamento imaxinativo e anárquico que dita a organización funcional do cerebro que determina os hábitos de pensar. $\mathrm{O}$ estudo realizado seguindo estas concepcións permitirá verificar ata que punto a estimulación nos tradutores do desenvolvemento do seu potencial recreativo para verter os versos polacos permitiu ao receptor percibir as calidades da realidade da partida. Así mesmo, demostraremos que a intencionalidade estética das representacións orixinais pode funcionar no contexto poético galego e español sen maiores inconvenientes.

Palabras chave: poesía; tradución; pensamento lateral; recreación; Wisława Szymborska.

\section{[en] "Capture the Most Subtle Conflicts of the Soul" in the Transaltion Process. The Poetry of Wisława Szymborska in Galician and in Spanish}

Abstract. The purpose of this article is to point out the possible translation obstacles encountered by translators when recreating the world depicted in the poetry of Wisława Szymborska, winner of the 1996 Nobel Prize for Literature. We propose to carry out a comparative study between the original verses and the Galician and Spanish versions to find out if the stylistic and formal structure of the works from which emerges "a very peculiar emotional and intellectual vibration, due to a mixture of very concrete observations and a sober lyrical tone, always attenuated by the irony" (Rodowska

$1 \quad$ Uniwersytet Warszawski.

Correo-e: a.jackiewicz@uw.edu.pl 
2008) has been preserved in the target texts. Our study will be based on the idea of the translation of lyrical texts as a reworking of the original in another language (Herrero Cecilia 1995) and on the theory of "lateral thinking" (De Bono 1970), that is, a mode of imaginative and anarchic reasoning, which dictates the functional organization of the brain that determines the habits of thinking. The analysis carried out following these conceptions will allow us to verify to what extent the stimulation in the translators of the development of their recreational potential to pour the Polish verses has enabled the receiver to perceive the qualities of the original reality. Likewise, we will demonstrate that the aesthetic intentionality of the Szymborska's representations can be a part of the Galician and Spanish poetic context without major inconveniences.

Keywords: Poetry; Translation; Lateral Thinking; Recreation; Wisława Szymborska.

Sumario. 1. Introducción. 2. Metodología. 2.1. Corpus de textos. 2.2. Pensamiento lateral. 2.3. Pensamiento lateral desde la perspectiva traductológica. 2.4 Traducción poética como recreación del original. 3. Estudio comparativo de los poemas originales junto con sus traducciones. 3.1. Análisis del poema "Nic dwa razy". 3.2. Análisis del poema "Pod jedną gwiazdką". 3.3. Análisis del poema "Liczba Pi”. 4. Conclusiones. 5. Referencias bibliográficas.

Como citar: Jackiewicz, A. (2019): “«Captar los conflictos más sutiles del alma» en el proceso de traducción. La poesía de Wisława Szymborska en gallego y en español", en Madrygal. Revista de Estudios Gallegos 22, pp. 209-221.

\section{Introducción}

Como indica Lucía Caeiro en su estudio introductorio, Wisława Szymborska:

Conseguiu situarse nos primeiros planos do panorama literario europeo e hoxe en día é considerada unha das maiores voces da poesía contemporánea mundial. (...) A poeta caracterízase sobre todo por amosar unha ollada filosófica profunda que ironiza agudamente en torno ás perplexidades e contradicións do mundo e do ser humano. Nos seus versos, partindo tanto dun mínimo incidente cotián como dun feito tráxico, capta os máis sutís conflitos da alma. O paso do tempo, a beleza, o amor, o odio, a dor, a morte, os soños, os pequenos detalles, a humanidade... aparecen mediante unha escritura enxeñosa, intimista e sinxela en aparencia. (2011: 7-8)

Esta creación poética atañe a los problemas sustanciales de la vida y la muerte. La poetisa relee el mundo, la realidad y todo lo que rodea al hombre, practica una relectura creativa del universo, mostrándolo a través del prisma de una sorpresa metafísica (Baranowska 1997: 43). Asimismo, predomina en los versos un lenguaje inusualmente sencillo en el que prevalecen locuciones coloquiales, carentes de énfasis, un lenguaje que es comprensible para cada persona que sepa polaco, pero que exige del lector -y del traductor- una gran minuciosidad interpretativa, puesto que se deposita en él una riqueza de significados y registros. La especificidad de dicha obra reside también en su forma y organización, dado que la autora "sorprende al lector utilizando no solamente la herramienta de la razón, sino, también, medios puramente poéticos como, por ejemplo, el cambio de ritmo, pues adopta deliberadamente un ritmo «simple» $\mathrm{o}$, al contrario, un ritmo «excesivamente artístico»" (Baranowska 1997: 25).

Igualmente, y teniendo en cuenta el carácter peculiar de la estrategia poética de Szymborska desde el punto de vista puramente traductológico, destaca la constatación de que "la finura de la palabra de la Premio Nobel pierde mucho en la traducción al español. Su lenguaje tiene una vibración emocional e intelectual muy particular. (...) Cada poema parece una joya, perfecta e irrepetible, que la poetisa elabora con la máxima discreción" (Rodowska 2008: 28). Una observación parecida la proporcionan Beltrán y Murcia Soriano subrayando que:

Traducir a Szymborska no es difícil, es dificilísimo. Y la gran dificultad radica precisamente en esa aparente sencillez y claridad. Cuando uno la lee en polaco tiene la sensación de entenderlo sin ningún problema. (...) La selección léxica que hace Szymborska es de una exactitud farmacéutica, no hay nada casual, las palabras ocupan el lugar que ocupan porque otras palabras ocuparán a su alrededor también un lugar preciso, pero el lector nunca será plenamente consciente de ello, la lectura resultará "ligera" y, sin embargo, la preparación de esa sencillez lingüística tiene que haber significado de gran esfuerzo, esfuerzo que se traslada al traductor cuando se enfrenta a la obra de Szymborska. Si a eso añadimos los juegos de palabras, los giros fraseológicos y su desdoblamiento posterior, las rimas, las aliteraciones y otros muchos recursos formales, que tienen que pasar inadvertidos, ya te imaginarás. (apud Szymborska 2014: 49-50)

Por otra parte, y a pesar de lo problemática que es la traslación de los poemas de la autora, esta manifestación artística merece una atención especial precisamente por el hecho de que en la historia de la traducción de la poesía polaca al español, el número de las versiones en dicho idioma sigue creciendo y sus autores constituyen un grupo de gran relevancia, pues destacan, entre otros, autores como Xaverio Ballester, Gerardo Beltrán, Elżbieta Bortkiewicz, David Carrión Sánchez, Maria 
Filipowicz-Rudek, Abel Murcia Soriano, Fernando Presa González, Krystyna Rodowska o Andrzej Sobol-Jurczykowski. Finalmente, merece resaltar también a Lucía Caeiro que ha hecho debutar los versos de la Premio Nobel en la lengua gallega.

\section{Metodología}

\subsection{Corpus de textos}

Contando con lo susodicho, es el propósito de nuestro artículo señalar la existencia de los poemas seleccionados de Szymborska en las lenguas gallega y española, así como verificar en qué medida los versos de partida pueden funcionar en los contextos poéticos meta. Para que nuestro estudio sea lo más objetivo posible y tomando en consideración la mencionada popularidad de esta obra entre los traductores hispanohablantes, examinamos tres obras que han sido traducidas más de una vez y en tiempos diferentes. Son los siguientes poemas: "Nic dwa razy", del poemario Wołanie do Yeti (1957), traducido por Lucía Caeiro, Krystyna Rodowska y Gerardo Beltrán; "Pod jedną gwiazdką", del poemario Wszelki wypadek (1972), traducido por Lucía Caeiro, Krystyna Rodowska, Andrzej Sobol-Jurczykowski y Sergio Hernández Rivera; "Liczba Pi", del poemario Wielka liczba (1976), traducido por Lucía Caeiro, Fernando Presa González y Carlos Marrodán Casas. Los textos meta provienen de cuatro antologías: Poesía Polaca. Antología (1984), Poesía polaca contemporánea. De Czesław Miłosz a Marcin Hałaś (1994), El gran número, Fin y Principio y otros poemas (1997), Poesía polaca contemporánea (2008), Versos escollidos (2011). Esta selección se debe también al hecho de que cada uno de estos poemas representa el mundo desde distintas ópticas, comprobando de esta manera la diversidad de cualidades de la creación poética de Szymborska a la que nos hemos referido con anterioridad.

\subsection{Pensamiento lateral}

Como punto de partida para reflexionar sobre las interpretaciones gallegas y españolas de los versos proporcionados por la poetisa, tomamos el enfoque propuesto por Edward de Bono (1970) y denominado "pensamiento lateral', reconocido a su vez por Albrecht Neubert (1986) como muy útil en el proceso de descubrir nuevas posibilidades en el proceso de traducción. En la opinión del psicólogo y médico maltés:
El pensamiento lateral está íntimamente relacionado con los procesos mentales de la perspicacia, la creatividad y el genio. Todos ellos tienen la misma base, pero se diferencian en que mientras estos tres últimos tienen un carácter espontáneo independiente de la voluntad, el pensamiento lateral es más susceptible de ser determinado por la voluntad consciente. Se trata de una forma definida de aplicar la mente a un tema o problema dado, como ocurre con el propio pensamiento lógico, pero de un modo completamente distinto. (De Bono 2000: 11)

Este tipo de pensamiento tiene como propósito la creación de nuevas ideas que propician un progreso continuo en distintos ámbitos, es decir, es la base del desarrollo científico y artístico, pero también de la evolución de la mente humana. Como añade el teórico, otra finalidad del pensamiento lateral consiste en:

La liberación del efecto restrictivo de las ideas anticuadas. Ello conduce a cambios de actitudes y enfoques, a la visión diferente de conceptos inmutables hasta entonces. La liberación del efecto polarizador de las viejas ideas y el estímulo de nuevas ideas es una doble función del pensamiento lateral. (De Bono 2000: 12)

Por consiguiente, el pensamiento lateral difiere fundamentalmente del pensamiento vertical, basado en el avance de las ideas a través de fases justificadas en sí mismas. Es más, se relaciona muy estrechamente con la creatividad, imprescindible no solo para la descripción de resultados, sino también para la descripción de un proceso, de ahí que tengamos que ver con un empleo de creatividad de manera consciente y deliberada (Ibid. 12-13). La creatividad, según De Bono, está rodeada de una aura mística, una destreza misteriosa que exige una sensibilidad estética y capacidad innata de expresión, pero para poder hacer pleno uso de esta es necesario extirparle este carácter y considerarla como un modo de manejar la información, utilizar la mente e intentar superar las limitaciones inherentes a ella (Ibid. 12).

\subsection{Pensamiento lateral desde la perspecti- va traductológica}

Las observaciones proporcionadas por De Bono resultan, a juicio de Neubert, fructíferas en el contexto traductológico y, sobre todo, para reflexionar sobre el carácter relativo de cada proceso de traducción, dado que "una elección demasiado apresurada de una estructura particular-que muchas veces es la más similar a la 
que está presente en el texto original- puede dificultar la adopción de una solución completamente diferente, y tal vez más efectiva" (2009: 138). La adopción del pensamiento lateral en la traducción conlleva una resignación de lo esperado y convencional e incentiva una mirada al texto de partida con otros ojos. El traductor reorganiza el tejido semántico del original, proponiendo un nuevo modelo léxico, gramatical o rítmico (Ibid. 139). Con la implementación del proceso de reconstrucción traductológica de esta manera, el traductor tiene la sensación de crear algo desconocido, mostrar el contenido del texto original desde una nueva perspectiva, no necesariamente contraria a la intención del autor. Como subraya el teórico alemán:

Un traductor siempre debe tener en cuenta no limitar su horizonte de creatividad por equivalentes una vez elegidos. Siempre debe tener delante de los ojos una unidad de traducción, siendo al mismo tiempo consciente de que esta es un mosaico de la totalidad de la visión revelada por el autor. (Ibid. 139)

Por lo que las decisiones traductoras individuales no pueden ser aisladas del resto de la estructura del original. Además:

Tal enfoque protege al traductor de enredarse en esquemas de palabras y estructuras gramaticales una vez establecidas. El pensamiento lateral y la relatividad traductológica posibilitan mantener la habilidad del traductor para pensar de forma creativa y así buscar soluciones aún más innovadoras y eficaces. (Ibid.)

\subsection{Traducción poética como recreación del original}

Igualmente, y teniendo en cuenta que desde nuestro punto de vista, la traducción de poesía, en la mayoría de los casos, constituye un ejemplo del arte recreativo, consideramos pertinente mencionar también la concepción de Juan Herrero Cecilia (1995: 273) sobre la traducción poética como actividad de recreación, reelaboración y re-escritura del texto original en otro sistema lingüístico y cultural. Cuestiones tales como la manera de representar el mundo observado, las estructuras rítmicas, métricas y estilísticas propias de los versos de Szymborska y sus versiones en gallego y en español serán objeto de reflexión basada en la pregunta reiterada de si es posible verter la poesía o si esta admite un proceso ilimitado de 'traducción-recreación' (Ibid. 280). En la opinión del traductólogo español, la poesía acepta muchas formas posibles de traducción, mientras que:

La menos poética (y por lo tanto la más infiel al discurso específico de la poesía que es ante todo expresión rítmica y musical del sentir y del pensar de un sujeto) es aquella que pretende ser fiel únicamente al sentido lógico-semántico de los versos del poema dejando a un lado la dimensión rítmica, musical y expresiva que hace del universo del texto una totalidad significante y una unidad de visión y de evocación. (Ibid. 280)

Por otra parte, la auténtica traducción de una obra versificada es aquella que recrea el texto como una obra para el receptor, aquella que pone en marcha un sistema de recursos estéticos análogos y cuya lectura ocasiona una sensación rítmica y evocadora similar a la que ocasiona la lectura del original (Ibid. 280). Precisamente en este contexto se estudian algunas soluciones adoptadas en las traslaciones gallegas y españolas de los poemas objeto de nuestro artículo.

\section{Estudio comparativo de los poemas origi- nales junto con sus traducciones}

\subsection{Análisis del poema "Nic dwa razy"}

En primer lugar, nos centramos en la obra "Nic dwa razy", proveniente del poemario Wołanie o Yeti (1957), que se hizo muy popular gracias a ser musicado y cantado varias veces y por distintos intérpretes. Como indica Baranowska:

Este poema sigue viviendo su propia vida. Ha tenido tal éxito porque, con sencillez inusual, presenta los rasgos característicos de la poesía de Szymborska, constituye la quintaesencia de lo que los lectores aman en su poesía, de aquello con lo que se identifican. En él la poetisa prueba que cada persona se mueve en un espacio filosófico, entre los asuntos mayores de la vida y la muerte, en medio de incesantes retos. (1997: 23)

Asimismo, constituye una síntesis de nuestra existencia y de nuestro paso por ella, que puede ser comprendida por todos, pero, al mismo tiempo, es también un poema de amor, como lo indican la cuarta y quinta estrofas (Baranowska 1997: 41). Igualmente, conviene resaltar que la obra llama la atención debido a su organización formal, es decir, al hecho de estar compuesta solo por los versos octosílabos que poseen rimas cruzadas asonantes y consonantes en las cláusulas de los pares. 


\section{Nic dwa razy}

Nic dwa razy się nie zdarza i nie zdarzy. Z tej przyczyny zrodziliśmy się bez wprawy i pomrzemy bez rutyny.

Choćbyśmy uczniami byli najtępszymi w szkole świata, nie będziemy repetować żadnej zimy ani lata.

Żaden dzień się nie powtórzy, nie ma dwóch podobnych nocy, dwóch tych samych pocałunków, dwóch jednakich spojrzeń w oczy.

Wczoraj, kiedy twoje imię ktoś wymówił przy mnie głośno, tak mi było, jakby róża przez otwarte wpadła okno.

Dziś, kiedy jesteśmy razem, odwróciłam twarz ku ścianie. Róża? Jak wygląda róża? Czy to kwiat? A może kamień?

Czemu ty się, zła godzino, $\mathrm{z}$ niepotrzebnym mieszasz lękiem? Jesteś - a więc musisz minąć. Miniesz - a więc to jest piękne.

Uśmiechnięci, wpółobjęci spróbujemy szukać zgody, choć różnimy się od siebie jak dwie krople czystej wody.

(Szymborska 2010: 28-29)

\section{Nada dos veces}

Nada ocurre dos veces y nunca ocurrirá. Nacimos sin experiencia, moriremos sin rutina.

Aunque fuéramos los alumnos más torpes en la escuela del mundo, nunca más repasaremos ningún verano o invierno.

Ningún día se repite, no hay dos noches iguales, dos besos que dieran lo mismo, dos miradas en los mismos ojos.

Ayer alguien pronunciaba tu nombre en mi presencia, como si de repente cayera una rosa por la ventana abierta.

\section{Nada dos veces}

Nada sucede dos veces ni sucederá, y por eso sin experiencia nacemos sin rutina moriremos.

En esta escuela del mundo ni siendo malos alumnos repetiremos el año, un invierno, un verano.

No es el mismo ningún día, no hay dos noches parecidas, igual mirada en los ojos, dos besos que se repitan.

Ayer mientras que tu nombre en voz alta pronunciaban sentí como si una rosa cayera por la ventana.

Ahora que estamos juntos, vuelvo la cara hacia el muro. ¿La rosa? ¿Cómo es la rosa? ¿Cómo una flor o una piedra?

Dime por qué, mala hora, con miedo inútil te mezclas.

Eres y por eso pasas.

Pasas, por eso eres bella.

Medio abrazados, sonrientes, buscaremos la cordura, aunque somos diferentes cual dos gotas de agua pura.

(trad. de Gerardo Beltrán en Szymborska 1997: 58-59)

\section{Nada dúas veces}

Nada sucede dúas veces nin vai suceder. Por iso sen experiencia nacemos e sen práctica morremos.

Inda na escola do mundo sendo alumnos moi burráns, non imos nunca repetir ningún inverno nin verán.

Ningún día será o mesmo, non hai noites similares, nin hai dous beixos idénticos, dúas miradas semellantes.

Onte, cando o teu nome dixeron á miña beira, foi como se unha rosa caese pola xanela. 
Hoy, cuando estamos juntos, vuelvo la cara hacia el muro. ¿Rosa? ¿Cómo es la rosa? ¿Es flor? ¿O tal vez piedra?

¿Y por qué tú, mala hora, te enredas en un miedo inútil? Eres, pues estás pasando, pasarás -es bello esto.

Sonrientes, abrazados, intentemos encontrarnos, aunque seamos distintos como dos gotas de agua.

(trad. de Krystyna Rodowska en Rodowska 2008: 29)
Hoxe, cando estamos xuntos, volvín á parede a cara.

Rosa? Que semella a rosa?

É flor? Ou pedra se cadra?

Por que ti, hora ruín, te mesturas con van medo? Es, logo tes que pasar. Pasas, logo isto é belo.

Riseiros, medio abrazados tentaremos do acordo a busca, inda sendo tan distintos como gotas de auga pura.

(trad. de Lucía Caeiro en Szymborska 2011: 13-15)
Antes de pasar al estudio contrastivo de las soluciones seleccionadas con respecto a la transferencia de la estructura lógico-semántica del poema original, queremos indicar que solo las versiones de Beltrán y Caeiro reflejan, en gran medida, la indicada regularidad rítmica, pues prevalecen en ellas los versos de ocho sílabas, así como aparecen rimas cruzadas. La traducción que más difiere del original es la propuesta por Rodowska. En este caso, la irregularidad de las rimas y de los versos, que suman incluso hasta once sílabas, se debe a la traducción literal -tanto a nivel léxico como sintáctico- que consigue transmitir las imágenes de partida, pero produce un 'empobrecimiento cualitativo' ${ }^{2}$ de la potencia expresiva del texto.

Dicha literalidad la demuestran los versos: Choćbyśmy uczniami byli / najtepszymi w szkole świata, traducidos como "Aunque fuéramos los alumnos / más torpes en la escuela del mundo" ( $\left.\mathrm{KR}^{3}\right)$. Aquí, la traducción palabra por palabra, aunque refleja perfectamente el nivel lógico-semántico de las líneas de partida, hace enturbiar su regularidad métrica, pues observamos el aumento en la longitud de los versos que suman nueve y diez sílabas, respectivamente. Un ejemplo parecido lo revela el fragmento: tak mi było, jakby róża / przez otwarte wpadta okno, sustituido por "como si de repente cayera / una rosa por la ventana abierta" (KR), donde los versos son deca- y endecasílabos, respectivamente, entonces de nuevo quedan afectadas la dinámica y expresividad de la imagen original.

Al reflexionar sobre las traducciones al gallego y al español de este poema, igualmente son de resaltar algunos fragmentos que demuestran la indicada recreatividad y consecuencia de sus autores. En este caso, nos enfocamos en soluciones empleadas en el verso spróbujemy szukać zgody, traducido como "buscaremos la cordura" (GB), donde el sustantivo polaco zgoda ('acuerdo', 'consentimiento') es reemplazado por el término 'cordura', relativo a "prudencia, sensatez, buen juicio" (DLE), que transmite completamente la intención icónica del original y, además, permite conservar la rima cruzada propia del esquema de partida formada por las palabras 'cordura' - 'pura'.

De igual modo interesante son los dos últimos versos de la obra: choć różnimy się od siebie / jak dwie krople czystej wody, vertidos al gallego como inda sendo tan distintos / como gotas de auga pura (LC). Cabe observar que desaparece en el proceso de traducción la palabra dwie (dúas), que forma parte de la expresión polaca jak dwie krople wody (como dúas gotas de auga), y en su lugar se introduce el adjetivo pura, relativo a auga, que también

Para mayor detalle véase Berman 2005: 15-16.

Empleamos las siguientes abreviaturas de los nombres de los traductores: GB (Gerardo Beltrán), LC (Lucía Caeiro), CMC (Carlos Marrodán Casas), FPG (Fernando Presa González), KR (Krystyna Rodowska), ASJ/SHR (Andrzej Sobol-Jurczykowski, Sergio Hernández Rivera).

4 Las traducciones provisorias de las respectivas palabras polacas, españolas y gallegas incluidas a continuación entre aspas simples y entre paréntesis son nuestras, a menos que se indique lo contrario. 
permite conservar la regularidad de ambos versos y la rima cruzada formada, en este caso, por las palabras busca - pura y, finalmente, propicia a su lector una imagen semejante a la que ha procurado la lectura del original.

\subsection{Análisis del poema "Pod jedną gwiazdką"}

El siguiente poema, que pertenece al poemario Wszelki wypadek (1972), lo hemos elegido por el hecho de ilustrar otras peculiaridades de la poesía de Szymborska. A saber, la obra está formada por versos-oraciones que generalmente son cercanos entre sí en la esfera del significado y en los que surge un mecanismo repetitivo del mismo concepto que se revela en el paralelismo sintáctico y la anáfora. Nos referimos a construcciones tales como: przepraszam przypadek; przepraszam konieczność; niech się nie gniewa; niech mi zapomna; wybaczcie mi; wybaczcie; daruj; darujcie mi; etc.

\section{Pod jedną gwiazdką}

Przepraszam przypadek, że nazywam go [koniecznością.

Przepraszam konieczność, jeśli jednak się mylę.

Niech się nie gniewa szczęście, że biorę je jak [swoje.

Niech mi zapomną umarli, że ledwie tlą się w [pamięci.

Przepraszam czas za mnogość przeoczonego [świata na sekundę.

Przepraszam dawną miłość, że nową uważam [za pierwszą.

Wybaczcie mi, dalekie wojny, że noszę kwiaty [do domu.

Wybaczcie, otwarte rany, że kłuję się w palec. Przepraszam wołających z otchłani za płytę z [menuetem.

Przepraszam ludzi na dworcach za sen o piątej [rano.

Daruj, szczuta nadziejo, że śmieję się czasem.

Darujcie mi, pustynie, że z łyżką wody nie [biegnę.

I ty, jastrzębiu, od lat ten sam, w tej samej klatce, zapatrzony bez ruchu zawsze w ten sam punkt, odpuść mi, nawet gdybyś był ptakiem

[wypchanym.

Przepraszam ścięte drzewo za cztery nogi [stołowe.

Przepraszam wielkie pytania za małe [odpowiedzi.

Prawdo, nie zwracaj na mnie zbyt bacznej [uwagi.

Powago, okaż mi wspaniałomyślność.

Ścierp, tajemnico bytu, że wyskubuję nitki z [twego trenu.
Nie oskarżaj mnie, duszo, że rzadko cię [miewam.

Przepraszam wszystko, że nie mogę być [wszędzie.

Przepraszam wszystkich, że nie umiem być [każdym i każdą.

Wiem, że póki żyję, nic mnie nie [usprawiedliwia, ponieważ sama sobie stoję na przeszkodzie.

Nie miej mi za złe, mowo, że pożyczam [patetycznych słów,

a potem trudu dokładam, żeby wydały się [lekkie.

(Szymborska 2010: 200)

\section{Bajo una misma estrella}

Pido perdón a la casualidad por llamarla [necesidad.

Pido perdón a la necesidad en caso de [equivocarme.

No se enoje la felicidad de que la tome por [propia.

No me guarden rencor los muertos por [apagarse en mi memoria.

Pido perdón al tiempo por la cantidad de mundo [que no percibo por [segundo.

Pido perdón al viejo amor por tener al nuevo [por primero.

Perdonadme lejanas guerras por llevar flores a [mi casa.

Perdonadme heridas abiertas por pincharme el [dedo.

Pido perdón a los que claman de lo profundo [por el disco con el minué.

Pido perdón a la gente en las estaciones por [dormir a las cinco de la [madrugada.

Perdóname, acosada esperanza, por reír de vez [en cuando.

Perdonadme, desiertos, por no correr tras una [cucharada de agua.

Y tú, gavilán, desde años el mismo, en la [misma jaula,

mirando inmóvil siempre al mismo lado, perdóname, aun si eres un ave disecada.

Pido perdón al árbol talado por las cuatro patas [de la mesa.

Pido perdón a las grandes preguntas por las [pequeñas respuestas.

Verdad, no me dediques excesiva atención.

Seriedad, muéstrate conmigo generosa.

Misterio de la existencia, deja que arranque [algunos hilos de tu velo.

No me acuses, alma, que no te poseo con [frecuencia.

(trad. Andrzej Sobol-Jurczykowski y Sergio Hernández Rivera en Suárez Recio 1984: 283-284) 


\section{Bajo una estrella}

Perdona, azar, que te llame necesidad.

Perdón, necesidad, si al tenerte me equivoco.

Perdonen, difuntos, que apenas los recuerde.

Perdón, tiempo, por todo lo que se me escapa [en un segundo.

Perdóname, viejo amor, que el nuevo me [parezca el primero.

Perdónenme, guerras lejanas, por traer flores a [casa.

Perdonen, heridas abiertas, que acabe de [pincharme el dedo.

Perdónenme los que claman desde el abismo [por escuchar ese disco de [minueto.

Perdónenme, los que corren en las estaciones, [por quedarme dormida al [amanecer.

Perdón, esperanza azuzada, porque a veces [estalle de risa.

Disculpen, desiertos, por no ofrecerles ni una [gota de agua.

Y tú, halcón, idéntico desde siempre, enjaulado, que miras fijamente el mismo punto,

perdóname, aunque seas un pájaro [embalsamado.

Discúlpame, árbol cortado, por las cuatro patas [de la mesa.

Perdón, grandes preguntas, por darles respuestas [fútiles.

Verdad, no me hagas demasiado caso.

Trascendencia, muéstrate generosa.

Soporta tú, misterio del ser, que no haga más

[que deshilvanar tu [solemne velo.

No me condenes, alma, por tenerte tan rara vez. Todo, perdóname si no estoy en todas partes. Me disculpo frente a todo por mi incapacidad [de ser cada uno o cada una.

Sé que mientras vivo, nada me justifica, pues yo mismo soy mi propio obstáculo. Lenguaje, no me tomes a mal por servirme de [tus patéticas palabras y luego empeñarme en que parezcan ligeras.

(trad. de Krystyna Rodowska en Rodowska 2008: 30-31)

\section{Baixo unha estreliña}

Que me perdoe a casualidade por chamala [necesidade.

Que me perdoe a necesidade, se porén me [equivoco.

Que non se anoxe a felicidade, se a tomo como [miña.

Que me esquezan os mortos que apenas están [latentes na memoria.
Que me perdoe o tempo pola cantidade de [mundo inadvertido nun [segundo.

Que me perdoe o vello amor por considerar o [novo como o primeiro.

Que me desculpen as guerras afastadas por [levar flores a casa.

Que me desculpen as feridas abertas por [pincharme nun dedo.

Que me perdoen os que claman dende o abismo [polo disco con minueto.

Que me perdoe a xente na estación polo soño [ás cinco da madrugada.

Que me dispense a esperanza acosada por rir [ás veces.

Que me dispensen os desertos por non correr [cunha culler de auga.

E ti, azor, dende hai anos o mesmo, na mesma [gaiola,

sen moverte, coa vista sempre fixa no mesmo [punto,

absólveme, aínda que sexas un paxaro disecado. Que me perdoe a árbore cortada polas catro [patas da mesa.

Que me perdoen as grandes preguntas polas [pequenas respostas.

Verdade, non me fagas caso con demasiada [atención.

Autoridade, móstrame magnanimidade.

Aguanta, misterio da existencia, que arranque [fíos da túa cola.

Non me culpes, alma, por sentirte poucas veces. Que me perdoe todo por non poder estar en [todas partes.

Que me perdoen todos por non saber ser cada [un e cada unha.

Sei que metres viva nada me xustifica, xa que por min mesma mo impido.

Non me reproches, fala, que tome prestadas [palabras patéticas

e despois me esforce para que parezan lixeiras.

(trad. de Lucía Caeiro en Szymborska 2011: 149-151)

Mirando los textos meta, esta vez también tenemos que ver con dos traducciones españolas y una gallega, desde el punto de vista formal, es inevitable notar que la primera versión es incompleta dado que se han vertido veintiún versos, mientras que el original consta de veintisiete líneas; la segunda está compuesta por veintiséis versos; y la gallega por veintisiete, siendo la única que mantiene la estructura del texto de partida.

Asimismo, la traducción de Caeiro se asemeja más al original también en cuanto a la transmisión del título del poema, ya que solo ella conserva el diminutivo polaco gwiazdka 
(estreliña). Por su parte, Rodowska, Sobol-Jurczykowski y Hernández Rivera emplean el sustantivo 'estrella', lo cual podríamos explicar tomando en consideración la observación de Beltrán y Murcia Soriano quienes subrayan que los traductores hispanos con frecuencia evitan el uso de los diminutivos al verter la poesía polaca porque:

En los poemas compuestos en español no es muy frecuente utilizar los diminutivos, puesto que su tono da al texto poético un carácter demasiado coloquial o incluso "dulzón", con lo cual surge la necesidad de diluirlos, también cuando se trata de una traslación. (1998: 169)

En lo que concierne a la transmisión en el proceso de traducción del arriba indicado paralelismo sintáctico y el empleo de la anáfora por la poetisa, cabe resaltar que en las versiones españolas se mantienen las expresiones originales, pues notamos locuciones tales como: "pido perdón" (ASJ/SHR); "No se enoje" (ASJ/SHR); "No me guarden rencor" (ASJ/ SHR); "Perdonadme" (ASJ/SHR); "Perdona" (KR); "Perdón" (KR); "Perdonen" (KR); "Perdónenme" (KR); etc. La autora de la traslación gallega proporciona una versión aun más regular que el original, puesto que emplea la anáfora Que me, por ejemplo, Que me perdoe, Que non se anoxe, Que me desculpen, Que me dispense, etc. Gracias a tal decisión, a nuestro modo de ver, el texto meta adquiere una potencia icónica más perceptible, también desde la perspectiva rítmica, de ahí consideramos la idea de la traductora muy acertada y conforme a la intención de Szymborska.

\subsection{Análisis del poema "Liczba Pi"}

Por último, prestamos atención al poema titulado "Liczba Pi", proveniente del poemario Wielka liczba (1976) en el que:

Entramos desde el primer momento de la lectura en un mundo poético que manifiesta sus lazos con el mundo contemporáneo, con la realidad actual de los fenómenos de masas, de los "grandes números", pero que, a la vez, intenta resistirse a la presión de la "ley de los grandes números". El instinto arrastra a la poetisa hacia "lo particular", la conciencia le obliga a hablar del mundo por encima de y más allá del individuo. (Baranowska 1997: 32)

La iconicidad de las imágenes construidas por la autora la refuerza también el hecho de señalar en cursiva ciertos versos o palabras particulares.

\section{Liczba Pi}

Podziwu godna liczba Pi

trzy koma jeden cztery jeden.

Wszystkie jej dalsze cyfry też są początkowe,

pięć dziewięć $d w a$, ponieważ nigdy się nie

[kończy.

Nie pozwala się objąć szesść pięć trzy pięć

[spojrzeniem

osiem dziewięć obliczeniem

siedem dziewięć wyobraźnią,

a nawet trzy dwa trzy osiem żartem, czyli

[porównaniem

cztery sześć do czegokolwiek

dwa sześć cztery trzy na świecie.

Najdłuższy ziemski wąż po kilkunastu metrach

[się urywa.

Podobnie, choć trochę później, czynią węże

[bajeczne.

Korowód cyfr składających się na liczbę Pi nie zatrzymuje się na brzegu kartki, potrafi ciągnąć się po stole, przez powietrze, przez mur, liść, gniazdo ptasie, chmury, prosto [w niebo,

przez całą nieba wzdętość i bezdenność.

O jak krótki, wprost mysi, jest warkocz

[komety!

Jak wątły promień gwiazdy, że zakrzywia się

[w lada przestrzeni!

A tu dwa trzy piętnaście trzysta dziewiętnaście

mój numer telefonu twój numer koszuli

rok tysiąc dziewięćset siedemdziesiaty trzeci

[szóste piętro

ilość mieszkańców sześćdziesią pięć groszy

obwód w biodrach dwa palce szarada i szyfr,

w którym słowiczku mój a leć, a piej

oraz uprasza się zachować spokój,

a także ziemia i niebo przemina,

ale nie liczba $\mathrm{Pi}$, co to to nie,

ona wciąż swoje niezłe jeszcze pięć,

nie byle jakie osiem,

nieostatnie siedem,

przynaglając, ach, przynaglając gnuśną

[wieczność

do trwania.

(Szymborska 2010: 240-241)

\section{El número Pi}

El número Pi es digno de admiración

tres coma uno cuatro uno

todas sus cifras siguientes también son iniciales

cinco nueve dos, porque nunca se termina.

No permite abarcarlo con la mirada seis cinco

$$
\text { [tres cinco }
$$

con un cálculo ocho nueve

con la imaginación siete nueve

o en broma tres dos tres, es decir, por

[comparación

cuatro seis con cualquier otra cosa

dos seis cuatro tres en el mundo. 
La más larga serpiente después de varios metros [se interrumpe.

Igualmente, aunque un poco más tarde, hacen [las serpientes fabulosas.

El cortejo de cifras que forman el número Pi no se detiene en el margen de un folio,

es capaz de prolongarse por la mesa, a través [del aire,

a través del muro, de una hoja, del nido de un [pájaro,

de las nubes, directamente al cielo

a través de la total hinchazón e inmensidad del [cielo.

¡Oh, qué corta es la cola del cometa, como la [de un ratón!

¿Qué frágil el rayo de la estrella que encorva [en cualquier espacio!

Pero aquí dos tres quince trescientos noventa mi número de teléfono la talla de tu camisa año mil novecientos setenta y tres sexto piso número de habitantes sesenta cinco céntimos la medida de la cadera dos dedos la charada y [el código

en la que mi ruiseñor vuela y canta y pide un comportamiento tranquilo también transcurren la tierra y el cielo pero no el número $\mathrm{Pi}$, éste no, él es todavía un buen cinco no es un ocho cualquiera ni el último siete metiendo prisa, oh, metiendo prisa a la perezosa [eternidad

para la permanencia.

(trad. de Fernando Presa González en Presa González 1994: 77-78)

\section{El número Pi}

Digno de admiración es el número Pi tres coma catorce.

Todas sus siguientes cifras también son iniciales, quince noventa y dos porque nunca termina. No se deja abarcar sesenta y cinco treinta $y$

[cinco con la mirada,

ochenta y nueve con los cálculos setenta y nueve con la imaginación y ni siquiera treinta y dos treinta y ocho con [una broma o sea

comparación

cuarenta y seis con nada veintiséis cuarenta y tres en el mundo.

La serpiente más larga de la tierra después de [muchos metros se acaba.

Lo mismo hacen aunque un poco después las [serpientes de las fábulas.

La comparsa de cifras que forma el número $\mathrm{Pi}$ no se detiene en el borde de la hoja,

es capaz de continuar por la mesa, el aire, la pared, la hoja de un árbol, un nido, las [nubes, y así hasta el cielo, a través de toda esa hinchazón e inconmensu[rabilidad celestiales.
Oh, qué corto, francamente rabicorto es el [cometa.

¡En cualquier espacio se curva el débil rayo de [una estrella!

$\mathrm{Y}$ aquí dos treinta y uno cincuenta y tres [diecinueve

mi número de teléfono el número de tus zapatos el año mil novecientos setenta y tres piso sexto el número de habitantes sesenta y cinco [céntimos

centímetros de cadera dos dedos charada y [mensaje cifrado,

en la cual ruiseñor que vas a Francia y se ruega mantener la calma y también pasarán la tierra y el cielo, pero no el número $\mathrm{Pi}$, de eso ni hablar, seguirá sin cesar con un cinco en bastante buen [estado,

y un ocho, pero nunca uno cualquiera, y un siete que nunca será el último, y metiéndole prisa, eso sí, metiéndole prisa a la [perezosa eternidad

para que continúe.

(trad. de Carlos Marrodán Casas en Szymborska 1997: 146-147)

\section{O número Pi}

Digno de admiración o número Pi tres coma un catro un.

Todas as súas cifras máis distantes tamén son [iniciais,

cinco nove dous, xa que nunca remata.

Non permite abarcalo seis cinco tres cinco coa

oito nove cun cálculo [mirada

sete nove coa imaxinación

e incluso tres dous tres oito en ton de broma, é [dicir, cunha comparación

catro seis de calquera cousa

dous seis catro tres no mundo.

A serpe máis longa da terra despois duns cantos [metros rompe.

Igualmente, se ben un pouco despois, actúan as [serpes das fábulas.

$\mathrm{O}$ cortexo de cifras que compoñen o número $\mathrm{Pi}$ non se detén na beira da folla,

é quen de prolongarse pola mesa, polo aire, pola muralla, unha folla, un niño de paxaros, as [nubes, dereito ao ceo,

por toda a inchabilidade e o senfín do ceo.

Oh, que curta, francamente ratonil, é a cola [dun cometa!

Que débil o raio dunha estrela que se dobra en [calquera espazo.

E aquí dous tres quince trescentos dezanove o meu número de teléfono a talla da túa camisa $o$ ano mil novecentos setenta e tres sexto andar a cantidade de habitantes sesenta e cinco [céntimos

contorno de cadeira dous dedos charada e [código, 
no cal quen puidera convosco voar e ademais rógase conservar a serenidade e tamén a terra e o ceo irán pasando, pero non o número $\mathrm{Pi}$, diso nin falar, el sempre co seu bastante bo aínda cinco, non con calquera oito non cun derradeiro sete, apurando, ai!, apurando á preguiceira [eternidade

para que perdure.

(trad. de Lucía Caeiro en Szymborska 2011: 185-187)

Contrastando la idea del poema original y sus interpretaciones en las lenguas gallega y española, resulta que solo las versiones de Marrodán Casas y Caeiro transmiten por completo el indicado empleo de letras itálicas en ciertos fragmentos de la obra. Al contrario, Presa González muestra una inconsecuencia, pues sus versos no quedan señalados conforme a la estrategia de Szymborska, puesto que hay pocas líneas o palabras que están en cursiva, lo cual podemos observar, por ejemplo, en el fragmento: mój numer telefonu twój numer koszuli y sus traducciones: "mi número de teléfono la talla de tu camisa" (FPG); "mi número de teléfono el número de tus zapatos" (CMC); "o meu número de teléfono a talla da túa camisa" (LC). Conviene comentar que la segunda propuesta no está en letras itálicas, con lo cual se aleja en mayor medida de la estructura original. En contraste, la traducción no literal de la locución numer koszuli ('número de camisa') ofrecida por Presa González y Caeiro, no provoca una modificación grave de la expresión construida por Szymborska. Es más, observamos aquí un empleo acertado del equivalente léxico propio de la lengua meta, pues se usa el sustantivo 'talla', mucho más frecuente en dicho contexto, entonces no surge la alteración de la imagen original. Una situación parecida la observamos en el cambio adoptado por Marrodán Casas, es decir, la introducción de la locución "el número de tus zapatos" que, a nuestro juicio, está conforme a la idea de la poetisa, puesto que se mantiene el sustantivo polaco 'número', pero cambia el accesorio de la vestimenta, que de ningún modo enturbia el verso de partida.

Para terminar nuestra reflexión, queríamos referirnos una vez más a la antes indicada exactitud farmacéutica de la poesía de la Premio Nobel. A saber, la potencia icónica de la obra analizada reside sobre todo en el valor numérico de Pi empleado por la autora, más concretamente, en sus veinticinco primeras cifras que aparecen en las líneas originales: $\pi \approx 3,141592$ 653589793238462643 , mientras que el resto de los números son invenciones propias de Szymborska. La idea se presenta en su totalidad de la siguiente forma: $3,1,4,1,5,9,2,6$, $5,3,5,8,9,7,9,3,2,3,8,4,6,2,6,4,3,2,3$, $15,300,19,1973,6,65,2,5,8,7$. Al examinar la transmisión de esta peculiaridad a ambas lenguas, resulta que solo la traducción gallega presenta una secuencia idéntica a la proporcionada por la poetisa, o sea, quedan transmitidos todos los treinta y siete números originales. Por otra parte, Presa González suprime en su versión el número ocho y en lugar del número diecinueve introduce el número noventa, en consecuencia de lo cual ofrece al receptor la siguiente secuencia: $3,1,4,1,5,9,2,6,5,3,5$, $8,9,7,9,3,2,3,-, 4,6,2,6,4,3,2,3,15,300$, 90, 1973, 6, 65, 2, 5, 8, 7. Marrodán Casas, por su parte, decide unir decenas y unidades hasta un cierto punto de la secuencia original, para luego continuar siguiendo el orden impuesto por de la autora. Por lo tanto, observamos el siguiente esquema: $3,14,15,92,65,35,89,79$, $32,38,46,26,43,2,31,53,19,1973,6,65$, $2,5,8,7$. Esta solución, en nuestra opinión y a diferencia de la propuesta de Presa González, no implica un enturbiamiento sustancial de la estrategia de Szymborska, pues puede producir solo una modificación a nivel rítmico con respecto al poema polaco.

\section{Conclusiones}

Para resumir nuestras observaciones, consideramos apropiado reconocer esta poesía, de acuerdo con el concepto de Umberto Eco, revelado en Obra abierta (1962), como una 'obra en movimiento' que se caracteriza por invitar a 'hacer la obra' con el poeta y propiciar una serie virtualmente infinita de lecturas e interpretaciones posibles - también en otros idiomas- de las que cada una lleva a la obra a revivir según una perspectiva y una 'ejecución' personal (1992: 44). Como sostiene el filósofo:

La "obra en movimiento" es posibilidad de una multiplicidad de intervenciones personales, pero no una invitación amorfa a la intervención indiscriminada: es la invitación no necesaria ni unívoca a la intervención orientada, a insertarnos libremente en un mundo que, sin embargo, es siempre el deseado por el autor. (Ibid. 43)

Además, las obras que, siendo físicamente completas, están 'abiertas' a "una germinación continua de relaciones internas que el usuario debe descubrir y escoger en el acto de 
percepción de la totalidad de los estímulos" (Ibid. 44). Y desde la óptica puramente traductológica, se trata de la realización de un proceso de traslación en el que uno intenta verter el poema en su conjunto semántico y formal de modo que ni el sentido se vea mermado por una literalidad que destruya la armonía estética y el significado de los versos, ni la forma se vea elogiada hasta el punto de traicionar la intención del original (Soto Bueno 2014: 95).

A la luz de lo susodicho, conviene admitir que tal como De Bono reveló la dicotomía entre el pensamiento vertical y el pensamiento lateral, Eco, en su obra La estructura ausente. Introducción a la semiótica (1968), propone contrastar la concepción del 'pensamiento serial' con la del 'pensamiento estructural'. Introduciendo la noción del pensamiento serial, el filósofo italiano resalta la eficacia de la idea de "individualizar códigos históricos y ponerlos a discusión para originar nuevas modalidades comunicativas" (Eco 1986: 328), dado que tanto que el pensamiento estructural, o sea, vertical, tiene como propósito 'descubrir', el pensamiento serial, en otras palabras lateral, intenta 'producir', proponer estructuras abiertas y ambiguas, sin imponer estructuras inmanentes o códigos originales cuyas reglas serían indiscutibles.

En este contexto, y refiriéndonos una vez más a las observaciones de Herrero Cecilia, podemos concluir que la especificidad de las obras originales revelada en todas sus traducciones gallegas $\mathrm{y}$, especialmente, en las traducciones españolas de Beltrán, Marrodán Casas y Rodowska (en el caso de su versión del poema "Pod jedną gwiazdką") testimonia que la poesía de Szymborska reconoce cierta variedad de recreaciones, sin perjuicio de la iconicidad de su estructura lógico-semántica y formal. Asimismo, creemos conveniente resaltar que cada una de las versiones de Caeiro, que constituyen el debut de los versos de la Premio Nobel en la lengua gallega, evidencia la destreza recreativa de su autora que, al mismo tiempo, consigue descifrar y ofrecer al lector meta la experiencia de la antes mencionada esencia de esta poesía que "xorde desa curiosidade e do asombro fronte á diversidade das cousas no mundo" (Caeiro 2011: 8). Además, las modificaciones observadas en los versos meta deben considerarse como sus características distintivas, convirtiendo dichos textos en poemas autónomos que pueden, sin mayor obstáculo, funcionar en el contexto cultural y literario de llegada. Finalmente, el esmero de todos los traductores citados en este estudio hace que las voces de Szymborska puedan ser escuchadas con una sencillez y afectividad indistintamente alucinantes respecto a las obras compuestas en polaco.

\section{Referencias bibliográficas}

Baranowska, Małgorzata (1997): "Wisława Szymborska, poeta de la conciencia del ser”, en W. Szymborska, El gran número, Fin y principio y otros poemas. Madrid: Ediciones Hiperión, pp. 15-43.

Beltrán, Gerardo y Abel Murcia Soriano (1998): "Mała antologia problemów przekładu poezji polskiej na hiszpański”, Między Oryginatem a Przekładem IV, pp. 167-181.

Berman, Antoine (2005 [1985]): "La traducción como experiencia de lo/del extranjero. La traduction comme éprevue de l'étranger", en C. Ángel, M. Pulido (trads.), Colección Hermes, Traductología: Teoría y Práctica. Cuadernos Pedagógicos 2, pp. 1-27.

Caeiro, Lucía (2011): “Limiar”, en W. Szymborska, Versos escollidos, Santiago de Compostela: Edicións Positivas, pp. 7-10.

De Bono, Edward (2000 [1970]): El pensamiento lateral. Manual de creatividad, en Equipo MMLB (trads.). Buenos Aires; Barcelona; México: Editorial Paidós.

DLE = Diccionario de la lengua española de la Real Academia Española, 23 $3^{a}$ edición, Madrid: Espasa, https://dle.rae.es/?w=diccionario [consulta: 08/09/2018].

Eco, Umberto (1986 [1968]): La estructura ausente. Introducción a la semiótica (trad. F. Serra Cantarell). Barcelona: Editorial Lumen.

(1992 [1962]): Obra abierta (trad. R. Berdagué). Barcelona: Planeta-De Agostini.

Herrero Cecilia, Juan (1995): "La traducción poética como reelaboración y recreación: análisis de versiones al español de poemas de Baudelaire y Verlaine", en F. Lafarga, A. Ribas, M. Tricás Preckler (eds.), La traducción: metodología, historia, literatura: ámbito hispanofrancés [Actas del III Coloquio de la Asociación de Profesores de Francés de la Universidad Española (APFFUE)]. Barcelona: Promociones y Publicaciones Universitarias, pp. 273-280 (https://dialnet.unirioja.es/servlet/articulo?codigo=2374525).

Neubert, Albrecht (2009 [1986]): "Względność translatoryczna", P. Zarychta (trad.), en P. Bukowski, M. Heydel (eds.), Współczesne teorie przekładu. Antologia. Kraków: Wydawnictwo Znak, pp. 125-142. 
Presa González, Fernando (1994): Poesía polaca contemporánea. De Czesław Miłosz a Marcin Hałaś. Madrid: Ediciones Rialp.

Rodowska, Krystyna (2008): Poesía polaca contemporánea. México: Universidad Nacional Autónoma de México.

Soto Bueno, Daniel Ricardo (2014): "Bases para la traducción-recreación al español de poemas escritos en francés", Entreculturas 6, pp. 89-114.

Suárez Recio, Marietta (ed.) (1984): Poesía Polaca. Antología. Ciudad de La Habana: Editorial Arte y Literatura.

Szymborska, Wisława (1997): El gran número, Fin y principio y otros poemas, M. Filipowicz-Rudek, J. C. Vidal (eds.). Madrid: Ediciones Hiperión. (2010): Wiersze wybrane. Kraków: Wydawnictwo a5.

(2011): Versos escollidos (ed. y trad. L. Caeiro). Santiago de Compostela: Edicións Positivas. (2014): Hasta aquí (trads. A. Murcia y G. Beltrán). Velilla de San Antonio: Bartleby Editores. 